\title{
Turkish Women Architects in the Late Ottoman and Early Republican Era, 1908-1950
}

\section{Özlem Erdoğdu Erkarslan}

To cite this article: Özlem Erdoğdu Erkarslan (2007) Turkish Women Architects in the Late Ottoman and Early Republican Era, 1908-1950, Women's History Review, 16:4, 555-575, DOI: 10.1080/09612020701445966

To link to this article: http://dx.doi.org/10.1080/09612020701445966

册 Published online: 16 Aug 2007.

Submit your article to this journal $[\pi$

Џلll Article views: 112 


\section{Turkish Women Architects in the Late Ottoman and Early Republican Era, 1908-1950}

\section{Özlem Erdoğdu Erkarslan}

This article examines the public status and educational background of Turkish women architects from 1908 to 1950. Writings on the history of architecture in Turkey, as in the West, have focused on heroic male figures. Key works produced before the late 1970s used data gathered mainly from Arkitekt, the first Turkish architectural magazine, whilst a second generation of Turkish architectural historians has preferred to investigate state and private archives. It is impossible to find a mention of women as architects in either bodies of work, although their contributions are indeed evident in the pages of Arkitekt. This article aims to fill some of these gaps in the highly gendered history of modern Turkish architecture by identifying and examining women's work as architects in Turkey in the first half of the twentieth century. It also explores the relationship between the women's liberation movement, the discipline of architecture, and modernization ideology associated with the Turkish Republic. It argues that women architects, who undertook important private commissions and were permitted to enter public competitions as anonymous entrants, did not encounter overt discrimination until the 1940s. Nevertheless, forms of indirect discrimination across the period served to silence women in the pages of the architectural press and to occlude them from key public commissions and offices.

\section{Introduction}

Women's omission from existing histories of modern Turkish architecture is not surprising given the comparative professional difficulties faced by women architects in

\footnotetext{
Özlem Erdoğdu Erkarslan studied architecture in Dokuz Eylül University in Izmir, Turkey. She was appointed as an assistant professor in the Department of Architecture at Izmir Institute of Technology in 1997. Research interests include anti-orientalism, contemporary architecture in Islamic countries and gender issues. She also teaches and conducts research as part of the graduate program of Women's Studies in Ege University. Correspondence to: Özlem Erdoğdu Erkarslan, Assistant Professor, Department of Architecture, Faculty of Architecture, Izmir Institute of Technology, Gülbahçe Kampüs, Urla, Izmir, Turkey. Email: ozlemerkarslan@iyte.edu.tr
} 
Europe, the United States, or Canada. What makes the story of early women architects in Turkey distinctive is that they were, in fact, awarded important commissions, were granted licenses, and practiced without encountering direct discrimination until the 1940s, when more conservative influences began to take hold and discrimination against women became explicit. This article is based on accounts of the work of women architects in Early Republican Turkey that were published in the pages of Arkitekt, the first and most highly respected architectural journal in Turkey. ${ }^{1}$ This study aims to identify women's contribution to Turkish architecture, to examine the support provided by the Turkish state for women's entrance into the profession, and to evaluate the impact of changing political agendas on their status.

The first Turkish women architects were not faced with direct opposition in the public arena, although pioneering women architects in Europe or the United States had to prove themselves to skeptical and often hostile public and professional audiences. ${ }^{2}$ Gender inequality and discrimination remained but took different tones and shapes. Turkish nationalism in the Early Republican era, like many other ideologies, created a privileged class of loyal women who were at the service of the regime. Although the government was consistent in its endorsement of the careers of the first women architects, especially in the early years of the Republican era, Turkish women architects experienced indirect discrimination, which is evident in their silence within the architectural media and the low percentage of women who ran their own private architectural businesses. The dominance of public commissions in the careers of the first Turkish women architects contrasts with the stereotyping of Western women architects in the interwar period as primarily designers of domestic housing.

In addition, the high profile given to architectural design in Turkey at the time also became another key factor behind the eminent positions accorded to women architects. Women architects succeeded in proving their skills and intelligence through many architectural competitions of the period. The awards won provided them with access to other profitable commissions. However, historians have overlooked the published works of women architects and their success in architectural competitions during the first half of the century. The reasons for this reticence in architectural historiography must be analyzed first and foremost.

Architectural historiography systematically overlooked the works of women architects for many years, not only in Turkey, but also in the Anglo-Saxon world. This is emblematic of the patriarchy that is deeply rooted within the profession of architecture as well as in the very act of history-writing. However, the influence of gender history on modern architectural historiography has become apparent since the 1990s with a proliferation of monographs, biographies, and archival collections relating to early women architects. Compensatory histories of modern architecture not only include discussions of women architects but also reject the idea that architecture must be monopolized by men. These works form an addendum to the 'major texts' of modern architectural history, which shaped twentieth-century Western architectural theory and have formed most of the discipline's canons.

In Turkey, the major texts on the history of modern architecture were mainly produced in the late 1970s and 1980s. These texts uncritically linked official ideology 
with the achievements of modern architecture. ${ }^{3}$ Their analysis was preoccupied with the definition of stylistic characteristics associated with different epochs in modern Turkish architecture. ${ }^{4}$ What was common for this first generation of architectural historians was their endorsement of Republicanism and Kemalism and their a priori acceptance of the official ideology.

The architectural culture of the early Turkish Republic increasingly became a topic of interest for international readers after the publication of two English-language books. The first is a collection of essays on Turkish modernity edited by Sibel Bozdoğan and Reşad Kasaba published in 1997, and the second is the history of Turkish architecture in the early Republican era written by Sibel Bozdoğan, published in 2001. ${ }^{5}$ These two exclusive works elucidated the interwoven relations between nationhood and modern culture in Turkey as well as the 'grey tones' and the 'in-betweens' particular to peripheral modernism.

Bozdoğan's book, Modernism and Nation Building, is on the way to becoming a primary reference source on the subject, especially for English-speaking readers. While the first generation of architectural historians in Turkey was completely immersed in official ideology, Bozdoğan prefers to make a critical analysis of Kemalist discourse. Her readings of Turkish modernity also demonstrate her concern with the followers of postmodernism and anti-orientalism in Western social theory. This kind of critical history of Kemalism and Republicanism provides a platform for questioning previously concealed subjects, such as the relationship between modernity, nationhood, architecture, and gender roles. Despite the novelty in Bozdoğan's approach to Turkish modernity, her work does not avoid the elitism that she criticizes, since she structures the entire story of Turkish modern architecture up until the 1940s around the same limited number of practicing architects who had been the focus of earlier writings on architectural history. Such a narrow selection of historical material, which only covers 'the eminent' and 'the dominant', unfortunately leaves a great majority of architectural works out of formal history writing. Thus, the history of modern architecture in Turkey is limited by an elitist ideology that is focused on a handful of well-known architects (undoubtedly all male) and is engaged in a profitless debate on stylistic purity. Uğur Tanyeli suggests that the history of modern Turkish architecture still lacks diversified points of view. He also claims that all theoretical texts concerning Turkish modernity and architecture are already tied into political history, and even the latest work of Bozdoğan does not escape this stereotyped narration. ${ }^{6}$

The invaluable contributions of women architects are evident in the records of architectural competitions or in architectural magazines like Arkitekt. In fact, controversially, Arkitekt has been one of the major sources of documentation for architectural history writing in Turkey, since archive collections relating to architectural education in the Early Republican era were lost through fire or political upheaval. The continued construction of Turkish modern architecture around the names of a few heroes and the theme of nationalism still remains, even in revisionist work, and a reassessment of the careers of the first generation of women architects in Turkey is still long overdue.

Thus the history of modern architecture in Turkey 'still needs to be rewritten' by involving the 'miscellaneous' and 'the excluded' in the story of the construction of the 
nation state. ${ }^{7}$ The names of the women architects mentioned in this study were selected neither because of the prominence of the buildings they designed nor their assertive speeches, but simply on the grounds of previous exclusion.

\section{Cultural and Political Contexts: 1923-1950}

It may be helpful to summarize the major shifts in Turkish political history in order to contextualize the relationship that is discussed in this article between the experiences of Turkish women architects and the process of women's emancipation that was promoted by the state. Shifting cultural paradigms in the period 1923-1950 will be identified alongside shifts in the political regime, which resulted in changes to ideas about architecture as well as to the status of women.

The emancipation of women by the state was a totalitarian movement, fired by the Kemalist elites of the Early Republican period. The privileges granted to women started with the establishment of the Civil Law in 1926, which included the abolition of religious marriage, repudiation and polygamy; it established family relations within a legal frame and introduced civil marriage, divorce, and inheritance rights. The state's revolutionary attempt at gender equality continued with the enfranchisement of women in municipal elections in 1930 and in national elections in 1934. These developments promoted Westernisation and brought equal rights for both parties:

As part and parcel of Turkey's modernization process in 1923, Turkish women were emancipated and Turkey became the only Islamic country that granted social, legal and political rights to women early in the twentieth century ... This small, privileged group was able to receive the same education as men and compete with them under the same conditions for jobs. ${ }^{8}$

When addressing the difference between an independent women's liberation movement and state 'feminism', many scholars question the meaning of 'equality' that was formulated through the legal amendments mentioned above. Second-wave feminist literature in Turkey has argued that the First Republican era created only an illusion of gender equality: the First Republicans used a small, controlled, minority of unveiled women to symbolize Westernization. It has been argued that:

The privileges enjoyed by middle-class women of the Republican period were not enjoyed by women of other classes and sections of society. Pastoralism and patriarchal relationships were dominant and those who enjoyed these rights in any real sense formed only a small percentage of the urban minority. Naturally, this minority compromised with Kemalism, due to the privileges they acquired, and questioned neither the sexism of Civil Law (man is the head of family; woman is deprived of her rights of inheritance; woman may not work without her husband's permission; woman who commits adultery is subject to more severe punishments etc.) nor patriarchal relationships. They did not wear the veil and they were 'liberated' women who could become pilots, doctors, or teachers. With this point of view, they must have thought that others too would be liberated through secularism, civilization, education, and westernization on the path Kemalism advised. ${ }^{9}$

On the other hand, there are still some counter-views that defend the interventions of the state as a response to the independent women's liberation movement that emerged 
in the late Ottoman period. According to this view, the comprehensive liberation of Turkish women on legal, political and social grounds was primarily the achievement of the Kemalist era.

The first years following the establishment of the Republic in 1923 were the years of cultural revolution, the success of which depended upon the effectiveness of official propaganda. There was a direct control of cultural and intellectual life by the state. Modern architecture and the status of women were the two major themes of the propaganda that promoted the Westernization cultural policy of the Turkish Republic.

The engagement of modern architecture with nationhood is one of the essential points emphasized in most current theoretical studies. ${ }^{10}$ The collaboration between modern architecture and Kemalism was evident in the rhetoric of the revolution, especially in the propaganda publication of the Turkish Republic_La Turquie Kemaliste-as well as in the works of the first modern architects in Turkey. ${ }^{11}$ After the Independence War, the reconstruction of the country was an extremely important issue for the new Republic. Apart from urgent physical needs, the Turkish Republic was in search of new symbols to represent its departure from an Ottoman past and culture. Architectural competitions became tools for the dissemination of a Republican modernizing ideology all over Turkey. ${ }^{12}$

The spirit of Kemalism and Republicanism started to lose momentum after the death of Atatürk in 1938. In addition, the cultural policies followed by the first government were nearly completed, so there were no reasons to pursue the propaganda program further. This also caused a deceleration on the emancipation of women by the state as well as on the reconstruction campaign. Yet, another shift in the cultural history of Turkey occurred during the 1950s when the status of both architecture and women drastically changed as a result of the conservative influence of the Democratic Party, which was empowered as the opposition party in the country after 1945. Even the Republican Populist Party, which promoted the progressivist, independent image of the modern Turkish woman, exchanged its feminist discourse for the more traditional image of mother and housewife, not only because of the impetus of the opposition party, but also to align itself with the Americanism that was shaping the post-war cultural milieu. ${ }^{13}$ Thus the women's liberation movement that had started in the Late Ottoman period was replaced with a moderate state feminism after 1923, which increasingly lost its impetus. After 1945 a conservative spirit diffused through Turkey's social institutions and the desire for women's emancipation was lost.

\section{Architectural Education for Turkish Women}

It became a widespread practice for wealthy young women from Istanbul to go abroad for their education (especially in literature and art) after 1908 when the Ottoman Empire was undergoing a period of reform. The emergence of women's magazines, similar to the ones in the West, can be linked with the return of women educated abroad. Women's magazines then played an important role in demanding higher education for women, especially in Istanbul. Young educated women also played an important role in the creation of an early women's liberation movement. ${ }^{14}$ 


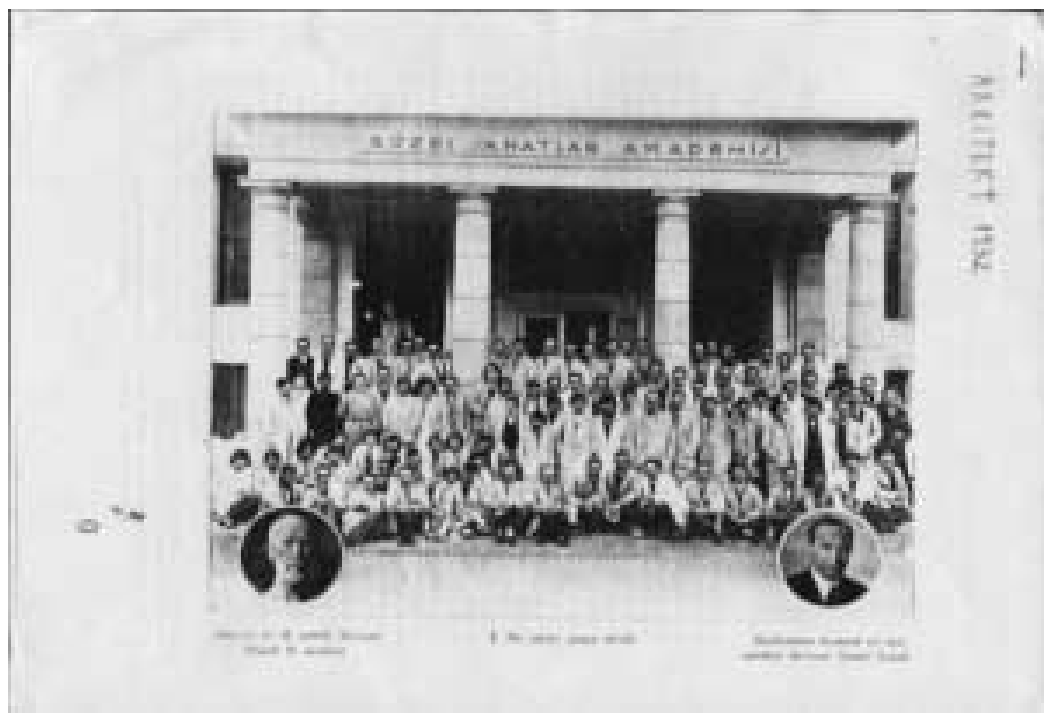

Figure 1. Students and teachers of the Academy of Fine Arts in 1928, İsItanbul. Source: Arkitekt, 1 (1932).

The first formal university for female students in Turkey was the School of Arts for Young Ladies (Inas Sanayi-i Nefise Mektebi) established in 1914 in Istanbul, which was renamed the Academy of Fine Arts in $1928 .{ }^{15}$ Although this school was initially supposed to offer art education only, it went on to inaugurate architectural education for women in 1928. There is no record of the professional careers of the first graduates of the School of Arts for Young Ladies so it can only be speculated that they pursued careers within the arts. In 1934 Leman Tomsu and Münevver Belen became the first graduates of the Department of Architecture of the Academy of Fine Arts (Figure 1). However, similar to the Académie Julian in France, the School of Arts for Young Ladies played a vital role between 1914 and 1928 in encouraging women to become involved in the field of architecture and in creating a positive public opinion of women's education as architects.

The involvement of Turkish women in professional careers during the Republican period reflects the dichotomies inherent within Kemalist ideology. Women's social and political rights had been granted by a male Kemalist elite as part of a wider reform package associated with the republic rather than as a result of high-profile campaigns by an active women's movement. ${ }^{16}$ Meltem Müftüler Bac has argued:

One should note that even though Kemalism had highly improved women's lot in Turkish society, the integration of women into the public sphere was possible only if women concealed their femininity and displayed modesty in their attire and behavior. The ideal woman is portrayed as pure, honorable and unreachable, serving the higher cause of modernization in Turkey. In that manner, Turkish women are seen as selfsacrificing, sacred creatures whose integration into the public sphere as teachers, nurses, and professionals does not threaten morality or order. ${ }^{17}$ 
Although the education of women was highly esteemed in the Republican period, the style of education was based on serious ideological restraints. ${ }^{18}$ The curricula within primary and secondary schools aimed to educate housewives and future mothers rather than professional, liberated women. Formal education in Turkey actually nurtured patriarchal family structures and intensified gender differences. ${ }^{19}$

The standardizing effect of formal education in Turkey prevented women from becoming involved in professions that required judgment, decision-making abilities, and creativity. In other words, the Kemalist regime created a seemingly Westernized liberal female figure, but did not actually remove the oppression of women that was embodied in all social institutions. Education in engineering, architecture, and the applied and pure sciences, which needed an advanced level of knowledge of mathematics or science, became unattainable for Turkish women who did not take advanced level courses in these fields during their high school education. In the early days of the Republican period, candidates who wished to attend universities had to take formal examinations, which were subject-specific, prepared by individual faculties. One of the reasons for the insignificant number of women architects in the 1930s and 1940s is the hindering effect of the preliminary examinations, which excluded women candidates with insufficient educational background in the disciplinary areas deemed relevant.

Civil engineering schools were another educational option for those embarking on an architectural career in Turkey, as in the United States in the late 1890s. Sabiha Ecebilen Güreyman and Melek Erbuğ were the first graduates of the school of engineering in Istanbul Technical University in 1933 and were probably the first Turkish woman professionals to deal with the built environment. Despite their specialization in engineering, both women worked on various bridge constructions in Anatolia. Although there were no official restrictions on the acceptance of female students into architecture and engineering schools, the working conditions in metropolitan areas like Istanbul, Ankara, and Izmir were still arduous for women who wished to pursue an active role at the construction site rather than a quiet role in the design office.

\section{The Changing Status of the First Women Architects}

Once qualified, the competition faced by pioneering women architects was less likely to come from their male colleagues than from foreign architects who held superior positions in the early years of the Republican era. This peculiarity of early modern architecture in Turkey seems to have prevented a potential battle between the sexes. Arkitekt was the only medium for Turkish architects to present their intellectual and practical work in these years. Key debates about the role of foreign architects took place within the pages of the journal in the early 1930s. The opposition of Turkish architects towards expatriates occupied the agenda more than any other subject. ${ }^{20}$

The Turkish Republic, upon its foundation in 1923, attempted to emphasize its novelty and divergence from the Ottoman Empire by moving the capital to Ankara and pursuing an intensive construction project in and around this new capital city. The city of Ankara, which was a small and undeveloped site at the beginning of the century, was extremely different in nature from Istanbul, which had epitomised the magnificence 
and prosperity of empire for centuries. The Turkish Republic reconstructed Ankara using a plain, rational architectural language that evoked modern aspiration rather than a historical past; thus it adopted the language of Eurocentric modern architecture in order to reflect its Westernization philosophy. The first public buildings were designed by European architects, including the buildings of the Grand Assembly of the Turkish Republic and even the master plan of Ankara. Local architects had to compete with these foreign architects more than with their national colleagues, especially during the 1930s. Local architects had to be content with small-budget projects for private employers at a time when all public projects were being offered to foreign architects. Turkish architects argued against this discrimination in articles addressed to the Prime Minister and published in Arkitekt, demanding instead that commissions for public buildings should be won through public competitions open to both local and foreign architects. Turkish architects must have been extremely gratified when Sevki Balmumcu, a talented Turkish architect, became a competition winner in $1933 .^{21}$

These architectural competitions, which became the only way for Turkish architects to develop substantial projects, were advantageous to women architects because entries were anonymised: a cipher was used instead of the name of the participant, thereby removing the most obvious marker of gender. Until the 1960s, architectural competitions dominated the architectural profession, reinvigorating it by introducing challenge, freedom of choice, and parity. Turkey closely paralleled Finland in this regard, where public architectural competitions had benefited young, as well as female architects, since the late nineteenth century: 'Because the competition entries were submitted under pseudonyms, the system permitted a democratic review of works and their relative merits without taking into consideration their authors'. ${ }^{22}$

Both architectural reconstruction and state-led women's emancipation in early twentieth-century Turkey were nurtured through nationalist tendencies that can be witnessed in all forms of peripheral modernity. ${ }^{23}$ As contemporary women's studies has theorized, however, modern Turkish women were granted 'liberation' under the Kemalist regime only in so far as it did not interfere with patriarchal heterosexual social relations. ${ }^{24}$ It is undeniable that women's liberation in Turkey was an elitist movement pioneered by a male bourgeois class, which required that women suppress their femininity when entering the public realm as professionals. Turkish women wanted to be liberated for the sake of the Republic, not for self-fulfillment, since gender inequality was overshadowed by economic considerations in the 1920s. Turkish women architects, like all other woman professionals in the country, internalized this dichotomy. It was under these political circumstances that the first Turkish women architects found themselves in the service of the Turkish Republic and Kemalism.

Unlike in the USA and Europe, the first half of the twentieth century was comparatively free of formal impediments for women architects in Turkey. They neither had to contend for the legalization of their existence in the profession, nor did they have to prove their professional qualifications in front of male colleagues. Similarly, there was no overt opposition to women architects in Turkey in the period 1934-1950, although many women architects in the West had to strive against tough criticism or campaigns against their professional performance. In fact, the first women architects in Turkey did 
not attempt to be 'stars' at all. Despite their 'silent' existence, their projects were included in Arkitekt without being questioned or criticized by their male colleagues. The word 'silent' is used intentionally here, because it is impossible to find a single sentence penned by a woman herself. Where their work is included, explanatory notes are written in the third person, without stating the personal view of the architect. However, the variety of public buildings that they designed is clear evidence of the support they received. ${ }^{25}$ In the USA, women architects were few in number and they tended to specialize in private housing projects: 'The field was inherently conservative, the scale of building was usually determined by individual needs and conservative practice, and the financial base was relatively modest, which further reduced their range of options'. ${ }^{26}$ Personal interviews with Turkish women architects demonstrate the vital role played by public commissions in their careers. These pioneering women were either directly assigned to the planning offices of state institutions or were given commissions for public buildings. Although they demonstrate pride in being modern women - just as Atatürk wanted them to become-they showed their aversion to being treated as heroes in any form. ${ }^{27}$

Yet the professional situation was not uncomplicated for women architects in Turkey. They shared with their male colleagues the difficulties associated with being underestimated in comparison to foreign architects. The number of architectural competitions was limited although they were the only opportunities to obtain relatively large-budget projects. Hence there were just four women members of the Union of Turkish Architects from 1934 to 1942. These architects were Leman Tomsu (member of Istanbul branch; born in 1913 in Istanbul; graduated from DGSA in 1934), Leyla Baydar (member of Ankara branch; born in 1924 in Eskişehir; graduated from DGSA in 1945), Celile Berk Butku (member of Istanbul branch; born in 1915 in Istanbul, graduated from ITU in 1942); and Harika Söylemezoğlu (member of Istanbul branch; born in 1918 in Istanbul; graduated from DGSA in 1942). Whilst competitions provided convenient working conditions and opportunities, working for private employers was not all that advantageous for them. Women architects frequently had difficulties in communicating with an employer during the preliminary design sketches. The privacy associated with traditional Turkish domestic life inhibited employers from discussing their expectations with the architect, especially when there was a gender difference. Wet areas and sanitary equipment were the most difficult matters that neither women architects nor their male employers were comfortable discussing with one another. For this reason, early woman Turkish architects preferred not to work on housing projects until modern sanitary standards were established in the 1960s. These social circumstances oriented women architects towards professional marriage partnerships, similar to other parts of the world, in which the male partner generally dealt with external business relations and the female partner worked behind the scenes.

\section{The Work of Women Architects in Turkey, 1934-1940}

As in many countries at the beginning of the twentieth century, architecture was obviously a male-dominated profession, and breaking into it was still a challenge, despite 
the encouragements of the regime in Turkey. In 1932, Arkitekt carried an article about the student exhibition at the Academy of Fine Arts, in which the name of Leman Tomsu first appeared, with coverage of her project for a hostel for 400 students. ${ }^{28} \mathrm{Her}$ first project prefigures the tendency towards simple prismatic compositions that marked the rest of her career. Her major concern in her designs was arranging the functions in a rational way, which sometimes caused her to ignore the mass composition and façade design. Despite her outstanding position as a pioneer woman who achieved a professional status equal to men, Leman Tomsu neither used her opportunities to advance the cause of women, nor reflected a remarkably different design attitude from her male colleagues. She was a fresh young architect who had graduated only a few months earlier when she was given the commission for the project of the Administration Buildings of the Republican Populist Party in Gerede and Emirdağ, two small towns in Anatolia (Figure 2). In the notes published in Arkitekt in 1934, it was stated that the commission was given specially to Tomsu by the general secretariat of the Republican Populist Party. ${ }^{29}$ This particular situation demonstrates how professional women were supported by the regime in Turkey in the 1930s.

The preference for simplicity of form in this design was interpreted in the design notes as 'the necessity of using the material and labor available in the area'. However, the less articulated building form is not particular to Tomsu's project. She followed the rational, safe language of modern architecture in the projects that she carried out on her own in the 1930s. Her designs were to 'live in', rather than to 'look at'. The conservative public taste in the small towns where her first projects were located might have prevented her from searching for a radical language of architecture. Like her other administrative buildings in small towns, the projects she developed in Gerede and Emirdağ resemble traditional vernacular architecture with their single-storey plans, elevated from the ground level with stone basement walls, and openings in the ratio of $1 / 2$, that were typical to the district.

When one looks at the careers of pioneering women architects in Turkey, it is striking to see that nearly all of the public commissions given to them were located in small towns. Harika Söylemezoğlu, one of the first architects in Turkey, stated in a speech that she was never commissioned to design a public building on one of the important

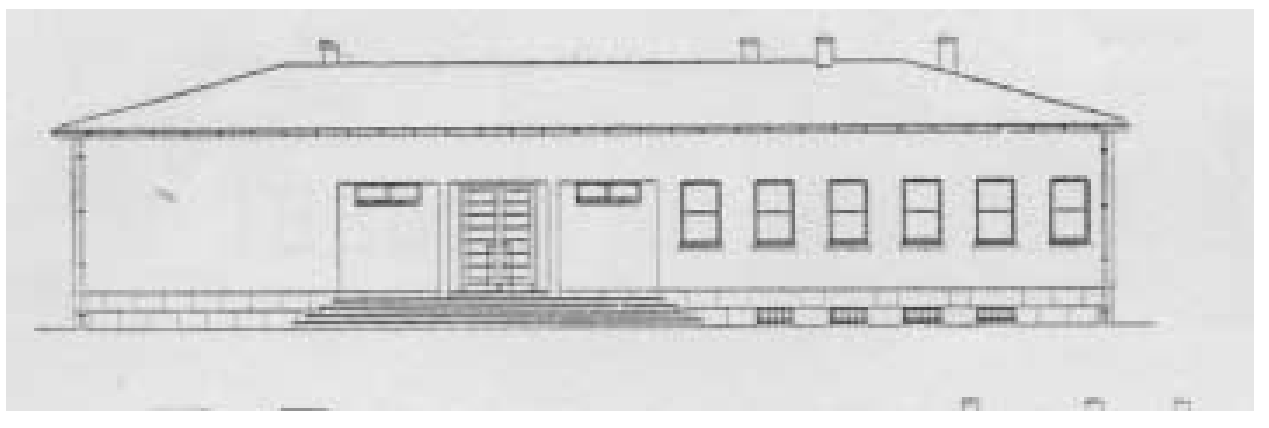

Figure 2. Administration buildings of the Republican Populist Party in Gerede and Emirdağ, Leman Tomsu. Source: Arkitekt, 3 (1934). 
axes of the city, but was generally assigned small-scale public buildings in small towns in Anatolia. ${ }^{30}$ This is symptomatic of the indirect discrimination faced by women architects and is suggestive of the contradictions rooted within the Republican era. In her speech, Harika Söylemezoğlu began by invoking a childhood memory of reading a poem on the occasion of Atatürk's visit to the primary school she attended. Her words acted as an endorsement of Atatürk and she had to pause several times whilst telling this story because of the emotions it generated. Throughout the speech she insisted on her debt to Atatürk for her career, since she felt it was he who had enabled her to become an educated woman. Söylemezoğlu stated that she never experienced sexual discrimination during her career but had always felt equal with men. On the other hand, at the end of her speech, she mentioned her disappointment at not being assigned to design an important public building in the city centre. The deep contradiction between her initial statements and her aspirations to work under the same conditions as male colleagues epitomises the status of the first women architects. The denial of sexual discrimination, obedience to the myth of equality, and loyalty to Kemalism were central elements within the professional identities of women architects, as of many other professional women in the early Republican Era.

The first women architects in Turkey mostly worked on public buildings that were modest in scale and located on accordingly less important sites. Their works were domestic in character and style, making use of the re-emergence of traditional vernacular themes. It is unclear whether the apparent domesticity of their designs was a result of their own preferences and biases or the requirements associated with a suburban location. The works that were cited in the architectural press were modest buildings located in 'şasrk'. The term refers to the cities and towns of Anatolia outside of Istanbul and Ankara, but it also implies the concepts of periphery and otherness, since these parts of Anatolia were believed to be less familiar with modernization and Westernization. Women's involvement in urban or important public building projects appears to have been the result of architectural competitions, thus demonstrating that women architects were only likely to be employed on small commissions if their gender was known. Outside of the competition framework, male colleagues were commissioned to work on important public buildings in Istanbul and Ankara.

In 1936 Tomsu collaborated with Münevver Belen, who had graduated from the Academy of Fine Arts in 1934, on The People's House in Karamürsel, another small town in the northwest region (Figure 3). ${ }^{31}$ The People's House in each town or city represented republican ideology and distributed the doctrines of Turkish modernization to the public. ${ }^{32}$ The building acted as an administrative centre for the Republican Populist Party and a multipurpose hall for public congregational activities. Architects preferred to designate the second floor as the party centre and left the ground floor for the double height multipurpose hall. The ground floor was also reserved for a library and several workshops.

Belen used a variety of distinctive urban forms in terms of both scale and style. Together, Tomsu and Belen developed a hybrid style. The geometrical composition of The People's House project in Karamürsel was more sophisticated than earlier projects. The double-storey building mass, accentuated with the long eaves of the hipped roof, 


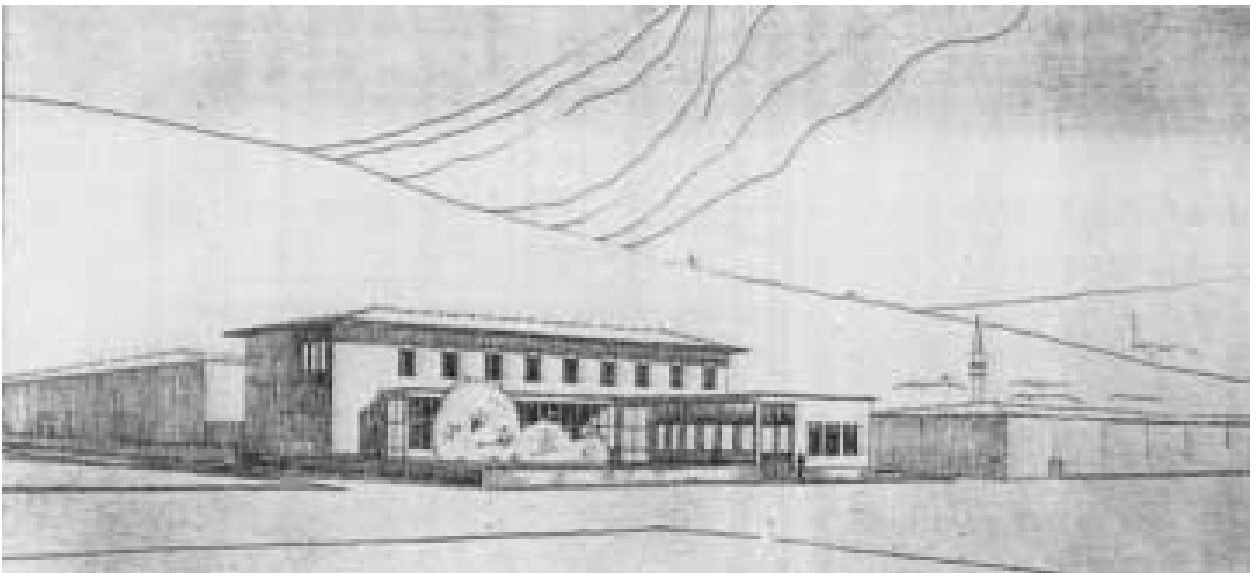

Figure 3. Karamürsel People's House, Leman Tomsu and Münevver Belen. Source: Arkitekt, 5-6 (1936).

was lightened with the attachment of a single-storey portico and transparent foyer. The design notes published in Arkitekt indicate that the treatment of the portico in this design was a common feature in vernacular architecture. The duality of urban and rural character present within modern Turkish architecture appeared in the formulation of the garden in front of the foyer in this project. The building faced toward a public square and the entrance was provided with a linear portico that left an unused open space to the side, organized as a garden rather than a courtyard. The preference for courtyard or garden gave either an urban or rural character to the building. The courtyard as a public gathering place was an important part of urban life, which tended to disappear from Turkish cities after the period of modernization. Tomsu and Belen chose to create a semi-urban character with a pseudo-courtyard that stands as a buffer zone between the main road and the building. The semi-urban character is neither peculiar to Tomsu and Belen, nor to their individual approaches. The urban/rural duality was ideological rather than stylistic and had not yet been resolved within Turkish modernist architecture. ${ }^{33}$

These two architects also collaborated on entries for architectural competitions and continued to work on several projects, one of which was the commission for The People's House in Kayseri in $1937 .{ }^{34}$ Kayseri is a historical city, located in the midAnatolian region, which kept its importance in the Seljuk and Ottoman periods. However, it is necessary to mention that Kayseri represents the oriental face of Anatolia; it is the very center of Islamic and conservative tendencies and is, thus, very different from the cities of Ankara, İstanbul or Izmir. An attentive analysis of this project would lead us to the same essential questions about the urban and rural duality stated above. The site plan showed similarities to the previous one by abandoning the principle of the hierarchy of open spaces. The building faced a 17-metre-wide street and embraced the site with its L-shaped mass. A passive green area was provided in front of the building, bordered by walls and isolated from the main street. This green area did 
not invoke the pastoral feeling of garden design; it was not a strong part of the overall composition and comes across as a left-over space, rather than a well-designed aspect.

On the other hand, the comprehensive building program was reflected in scale and in the elaborate geometrical composition. The multipurpose hall for approximately 1000 users was designed to be suitable for film projection, performance, and balls. These kind of multipurpose halls were a necessity in the cities of Anatolia since the limited economic conditions of the country did not allow the construction of separate complexes for specific purposes in the 1930s. Tomsu and Belen attentively provided a gallery for the projection room and spectator area, a backstage including dressing rooms and storage in the basement, and chose a flat-surfaced floor instead of a sloping one for the hall in order to house three of these separate activities within the same space. Despite the complexity of the programme, the façades were presented as a unified whole, combining modern monumentality with the symbols of traditional vernacular architecture.

Tomsu and Belen nevertheless continued to take on separate commissions in addition to their common ones. They published details of one more joint work, a detached house project in Ankara in 1937, in Arkitekt. ${ }^{35}$ This is the first time that these two architects were working in the capital city but, surprisingly, not on a public building but on small private housing. The house had strong references to vernacular architecture on the façades, although it was identified as a modern house on the plan. Belen and Tomsu were attentive to contemporary trends in art and architecture, but their dependence on traditional construction techniques somehow limited them to a traditional domestic image of housing. They were influenced by vernacular architecture and tried to reflect the nationalist tendencies in the Turkish architecture of the period. This approach is unlikely to have been appreciated since housing was exclusively understood in conservative terms in 1930s Turkey. The change in the lifestyle that modernism proposed was an abrupt leap. Although people were ready to accept new modes of everyday life, stylistic conservatism remained for a long time, especially in private housing projects.

Leman Tomsu was one of the favorite architects of the Republican Populist Party. She was given the commission for The People's House Project in the district of Şehremini in 1938 (Figure 4). ${ }^{36}$ At that point, Tomsu was working in the Planning Department of Istanbul Municipality. She had gained enormous self-confidence in the intervening years and became a respected architect. She then became specialized in developing community centres and was ready to experiment with new forms. Tomsu applied functional solutions that she had discovered through her previous experiences of building community centres. The location of the project in an important district in the city affected her architectural response and she found enough challenges to be liberated from traditional forms. The project was distinctive in its geometrical composition, which was a juxtaposition of curvilinear and rectangular prisms. The overall quality of form demonstrated a certain degree of maturity, although there were some weaknesses, especially in the joining point of orthogonal and curvilinear geometry, which deserved a more detailed articulation. The rough intersection of independent forms was also a common problem for her Turkish contemporaries. Her respect for gardens was evident in this project with the landscaping of a backyard area (which was too small to use for 


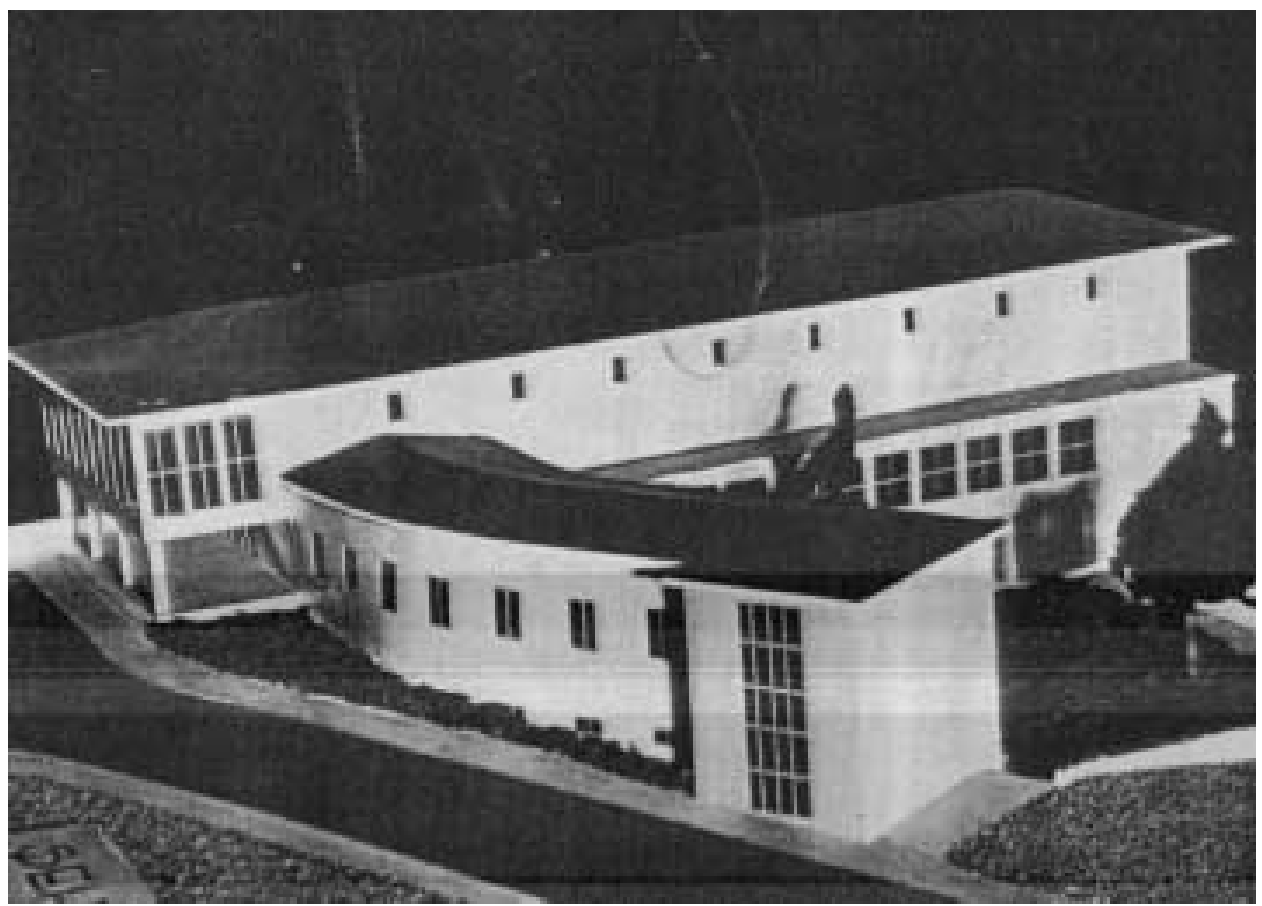

Figure 4. Şehremini People’s House Project, Leman Tomsu. Source: Arkitekt, 9 (1938).

outdoor sports activities). It is implied in the design notes, published in Arkitekt, that she was aware of the potential of this open space; although its landscaping served no immediate pupose, it could be developed as an amenity in the future. Also in 1938, Tomsu won third prize in the architectural competition for The People's House Project in Kadıköy. ${ }^{37}$ Her proposal was quite similar to the second prizewinners' proposal and had the same weaknesses in design principles: a prism construction with unbalanced horizontal and vertical openings, and a lack of unity in the whole. Architects attempted to justify the immaturity of the language of early modern Turkish architecture by referring to the principle of functionalism or constructional rationality.

\section{Women's Architectural Work, 1940-1950}

From the 1940s onwards there was a remarkable proliferation in the number of professional couples, such as Şekure-Lütfi Gürtuna, Nezihe-Pertev Taner, Harika-Kemali Söylemezoğlu and Leyla-Firuzan Baydar, who carried their partnership into architectural offices. The Taners, in their 'Master Plan of Rize City', proposed a programme of works that would enable civil servants to own houses in the city that would be designed to take into account topography, climate, and orientation and would be constructed through a load-bearing system. The project notes present the career civil servant as a symbol of modernity and the alternative lifestyle associated with it. It is noteworthy that even the smallest unit was four-roomed although financial difficulties were 
identified as a major concern during the design process. The Taners also worked on Mardin City's Reconstruction Plan, published in $1949 .{ }^{38}$ Leyla Turgut was another outstanding name in competitions of this period; together with Asim Mutlu, she was awarded the honorable mention prize for their entry in the Çanakkale Victory Monuments Competition in 1944. ${ }^{39}$

The Istanbul Broadcasting Studios Competition of 1945 also received a number of noteworthy entries from women, including a joint proposal from Celile Berk and Haydar Yücelen. ${ }^{40}$ The immature language of modern architecture of the 1930s had become clearer and its structural features had been canonized in the 1940s. The common themes of the First National Movement had been systematically duplicated and generalized. The grading of competition entries had depended to a large extent on the solutions offered by designers to the need for a blind front to the broadcasting studios. All competition participants recognised that it was symbolically important for the building structure to face the city, given that the studios were so obviously a tool for modernization as well as a symbol of it. The projects of Berk and Yücelen were based on the reliable principles of balanced mass composition and opening proportion. The Kemali-Harika Söylemezoğlu partnership also participated in the competition.

While the characteristics of national architecture were being established through competitions, women architects, on the other hand, were gradually gaining the benefits of experience. Those women architects who are named in the pages of Arkitekt, especially in the second half of the 1940s, draw attention because they were undertaking projects of equal standing to male colleagues. Thus, more equal competitive conditions were becoming commonplace. Leyla Turgut and Suat Erdeniz shared the second prize in the Cinema-Hotel Competition in Ankara in $1946 .{ }^{41}$ None of the works were found to be worthy of the first prize by the jury of this competition. In many respects Leyla Turgut's proposal looks surprisingly better than that of Erdeniz, with its coherence and strong character to the front façade, reflecting the taste of the period.

The Şişli Finance Department Building, designed by Münevver Belen in 1946, is a simple, yet striking building (Figure 5). ${ }^{42}$ Window openings formulated in horizontal frames (which are one of the characteristics of the period) were given depth with design elements such as a horizontally emphasized roof plane. Coherent proportions transformed a simple prism design into one evocative of a delicately embroidered jewelry box. Belen's sensitivity as a designer requires much more extensive research. The consistent style and quality of her work since the 1930s is impressive. For the Bursa People's House Competition, in which she was awarded the first prize in 1938, she proposed a very successful courtyard-type plan. ${ }^{43}$ It is immediately apparent that she was more qualified in the language of modern architecture than her contemporary, Tomsu.

In addition to the results of project competitions, plans for other buildings designed by women architects were also published in Arkitekt. One of these few examples is the simple peripteros plan by Nihal Sanl for the Society for the Protection of Children Pavilion in Izmir Fair, which was published in $1944 .{ }^{44}$ This building, fitting the conductive and simple concept of the Fair buildings, is an extremely successful application with makes use of a wooden structure. Sanlı also designed dwellings for the civil 


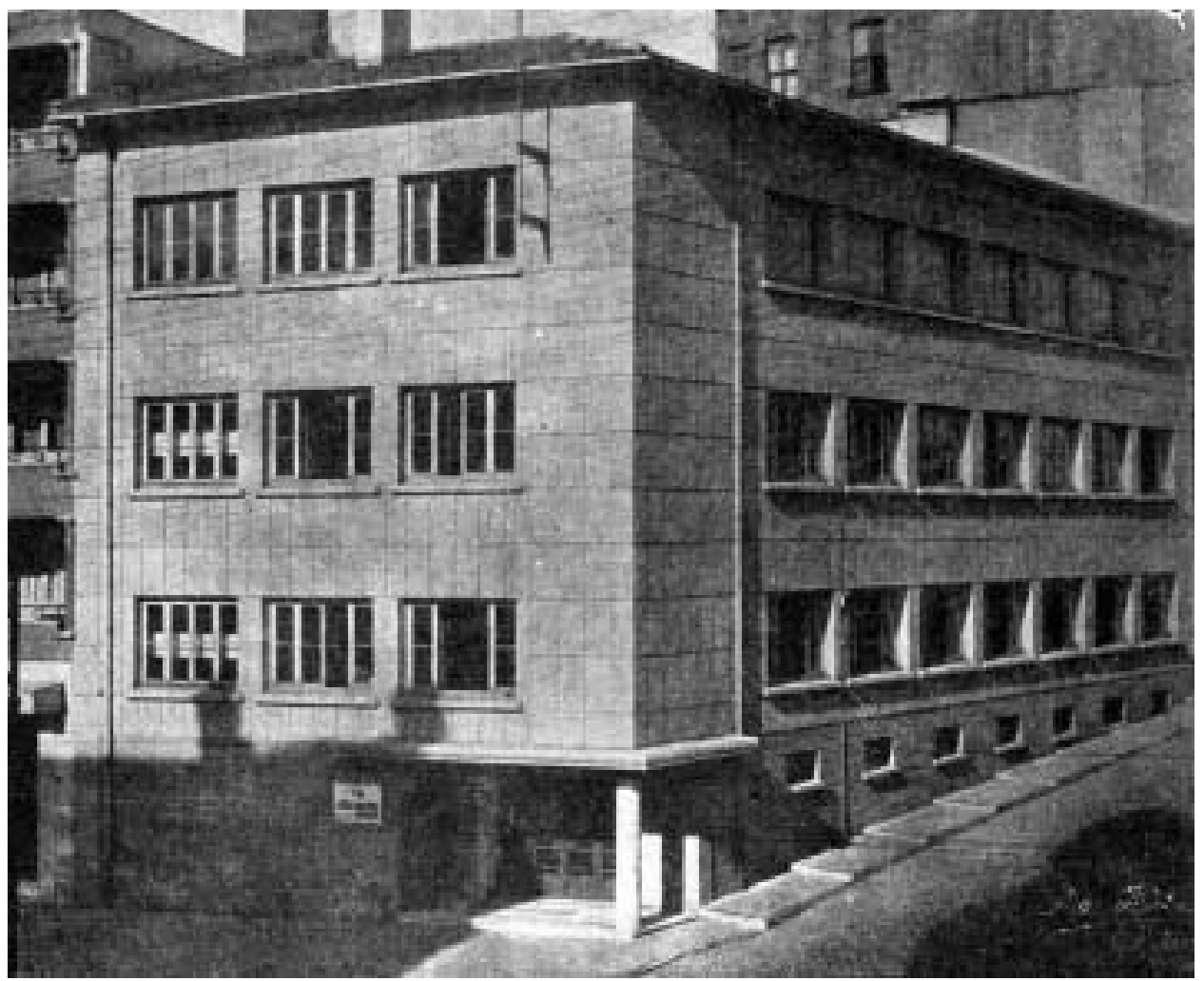

Figure 5. Şişli Finance Department building, Münevver Belen. Source: Arkitekt, 9-10 (1946).

servant, technician and foreman in Adana. ${ }^{45}$ It is known that Western women architects were amongst the first to study public housing, especially in the first quarter of the twentieth century. The work of Nihal Sanlı reflects a similiar interest in the problem of public housing during the 1940s. Design notes, published in Arkitekt, emphasized an urgent need for healthy, modern, housing for technicians and civil servants all over the country.

\section{Conclusion}

The first women architects in Turkey were neither socially nor poetically sensitive to the gendered constructions of the built environment. Since they primarily felt themselves to be defenders of Kemalism, they consented to leave their gender behind for the sake of the Westernization movement. Turkish women architects in the 1930s and 1940s were not marginalized in terms of being outside of a male-dominated profession. State-led 'feminism' provided ample opportunities for women to compete with their male colleagues. The image of modern women was a symbol of the secular identity of the Republic against the Ottoman past. Since women's contribution in the public 
sphere had been traditionally inhibited in Islamic culture, the revolutions of Kemalism created the image of unveiled, modern, professional women who were partners with their husbands, good mothers who raised the children of the Republic, and defenders of secularism.

The seemingly liberated role of Turkish women given by a Kemalist male elite probably prevented the emergence of gender discourse in the profession for a very long time. It has been argued that 'the presence of an emancipated small group of women does more harm to women in Turkey because it creates the illusion' that Turkish women architects had never been subject to gender discrimination. ${ }^{46}$ The gender discrimination that Turkish women architects faced historically was not a direct refusal to admit them to the profession; instead it is derived from the patriarchy concealed within Kemalism that hindered the emergence of an independent women's liberation movement.

The women's liberation movement in Turkey still suffers from inconsistency and elitism, which has prevented it from reaching a wider social base. State-sponsored 'feminism' guaranteed the entrance of Turkish women into the public sphere earlier than many other European countries, and the women of the Republic, in turn, guaranteed the secular identity with their devotion to Kemalism. Yet the abolition of Türk Kadınlar Birliği (the Turkish Women's Union) in 1935-the only women's party in the Middle East at that period of time - by external forces against the party's will, marks the oppression and interruption of an independent women's movement. The Women's Party found itself in an untenable position by the end of 1934 when the support coming from the Republican Populist Party had stopped. While the Women's Party was seemingly successful in achieving the right to vote and to be elected by 1934 , their larger goal of participation has remained unfulfilled since women's parliamentary ratio has never exceeded 8-9\% in the 72-year history of the Republic. Regrettably, the Women's Party was forced to abolish itself in 1935 when the feminist movement in Turkey was 'cleaned out' until the 1980s. The dark period of feminism in Turkey became even darker after the 1950s when the Democrat Party, drawn from the conservative wing, came into power. The great majority of women's associations in Turkey worked for the continuity of secularism between 1950 and 1980 and rejected the gender inequality that had been enshrined in constitutional law and which accepted the husband as the leader of the family structure. ${ }^{47}$

The first generation of women architects in the Republic were employed either through public commissions, in the private sector, or as state officers in planning departments. The first graduates worked directly for the Republican Populist Party (until the 1940s) whereas a second generation preferred to work in the urban planning departments of the Ministry of Public Works, the Iller Bank (Municipal Credit Bank) or in various municipalities. These posts were privileged positions with high salaries. Yekta Özgüven states that a new research assistant in a university was likely to be earning 150 TL a month in 1954 whilst an architect in a public post could earn $2000 \mathrm{TL}$ a month. ${ }^{48}$ Yet women architects in planning departments were unable to make a reputation through their design work, which remained anonymous. 
In addition to the numerous projects that women designed, the scores they achieved in competitions led to their appointment as ajudicating panel members. This meant an increase in the indirect effect of women architects on the constructed environment. Nevertheless, Turkish women architects have been increasingly marginalized in the profession. Turkish women architects never searched for sisterhood and solidarity, or attempted to collaborate in women's unions, which have been actively working as separate societies in Western architecture since the early 1930s. So-called gender-neutral discourses are woven so deeply into the discourse of Turkish architecture that even women architects themselves strictly avoid gender-based approaches or identities. ${ }^{49}$ This subject was a tabula rasa until the beginning of 2002, when the first gender-based studies in the field of architecture emerged in the building press in Turkey.

Early Turkish women architects always stayed a step behind their male contemporaries, and did not attempt to be stars, as was typical of all Turkish professional women of the period. Despite their success in project competitions, they never gave speeches or played the role of protagonist, unlike their male counterparts. Architectural historiography has systematically discarded Turkish women architects by ignoring both the existence of their successful works and the stories of their careers. This article has shown that while women found opportunities to work as architects during the early part of the modernization process, the rhetoric of equality was superficial since it was, ultimately, designed to serve the needs of a patriarchal system. The illusion of gender equality in the profession of architecture in modern Turkey hindered the development of a strong feminist identity amongst women architects.

\section{Notes}

[1] I wish to acknowledge the contribution of my postgraduate students-Yüksel Pöğün, Gökhan Kutlu, Nevin Ay, Kıvılcım Duruk, Zeynep Doğan, Arda Beset and Nilüfer Kutlu—who carried out archival research for this study whilst engaged on the course 'Women in Architecture' at the Izmir Institute of Technology. The first analysis of this research was published in Turkish: Özlem Erdoğdu Erkarslan (2002) Modern Türkiye’nin İnşasında Kadın Mimarlar, in Çağdaş, Mimarlık Sorunları Mimarlık ve Kadın Kimliği (İstanbul: Boyut Yayın Grubu), pp. 27-65. In 2002 this project was awarded the Milka Bliznakov Prize, by the International Archive of Women in Architecture, Virginia Polytechnic Institute and State University; this commendation encouraged me to work towards further publication. Jennifer Fraser edited the English version of the text several times and helped me to clarify my thoughts.

[2] For the discrimination experienced by women in Canada and the USA, see http://www.collectionscanada.ca/women/002026-407-e.html and http://www.distinguishedwomen.com/biographies/hayden-s.html (both accessed 17 February 2006). For women architects in Germany, see Katerina Ruedi Ray (2001) Bauhaus Hausfraus: gender formation in design education, JAE, 55(2), pp. 73-90.

[3] İnci Aslanoğlu (1980) Erken Cumhuriyet Dönemi Mimarlı̆̆ (Ankara: METU Faculty of Architecture); Metin Sözen (1984) Cumhuriyet Dönemi Türk Mimarlı̆̆ 1923-1983 (Ankara: Türkiye İş Bankası Kültür Yayınları); Metin Sözen \& Mete Tapan (1984) 50 Yılın Türk Mimarisi (Ankara: Türkiye İş Bankası Kültür Yayınları); Üstün Alsaç (1976) Türkiye’deki Mimarlık Düşüncesinin Cumhuriyet Dönemindeki Evrimi (Trabzon: İTÜ Mimarlık Fakültesi). 
[4] These styles have been categorized as follows: the First National Architectural Era, Novel Architecture (or sometimes referred to as cubic architecture), and the Second National Architectural Era.

[5] Sibel Bozdoğan \& Reşat Kasaba (Eds) (1997) Rethinking Modernity and National Identity in Turkey (Seattle: Publications on Near East, University of Washington), pp. 113-132; Sibel Bozdoğan (2001) Modernism and Nation Building: Turkish architectural culture in the Early Republic (Seattle: University of Washington Press), published in Turkey as Sibel Bozdoğan (2002) Modernizm ve Ulusun İnşası Erken Cumhuriyet Türkiyesi’nde Mimari Kültür (Tuncay Birkan, Trans.) (İstanbul: Metis Yayınları).

[6] Uğur Tanyeli (2004) İstanbul 1900-2000 Konutu ve Modernleşmeyi Metropolden Okumak (İ stanbul: Akın Nalça), pp. 37-38.

[7] Royston Landau (1991) The History of Modern Architecture that Still Needs to Be Written, AA Files, 21, pp. 49-54.

[8] Meltem Müftüler Bac (1999) Turkish Women's Predicament, Women's Studies International Forum, 22(3), p. 303.

[9] Mine Ege, Feminism in Turkey. Online document. http://flag.blackened.net/revolt/turkey/ may5 (accessed 19 January 2006).

[10] Baydar Gülsüm (2002) Tenuous Bondaries: women, domesticity and nationhood in 1930s Turkey, Journal of Architecture, 7(3), pp. 229-244.

[11] For references to the relation between Kemalism and modern architecture, see İnci Aslanoğlu (1986) Evaluation of Architectural Developments in Turkey within the Socio-economic and Cultural Framework of the 1923-1938 Period, METU Journal of the Faculty of Architecture, 7, pp. 15-41.

[12] Elif Özçelebi (1999) An Inquiry on the Impact of Competitions in Architectural Practice: documentation of architectural design competitions in Turkey between the years 1931-1969 (Master's thesis, Middle East Technical University, Ankara); Yasemin Sayar (1998) The Impact of Architectural Design Competitions in Evaluation of Architectural Design Trends for a Secular Identity 1933-1950 (Ph.D. thesis, Dokuz Eylül University, Izmir).

[13] During the Cold War period the Turkish government attempted to ally with Western countries in order to overcome the post-war economic crisis, although Turkish international policy had remained neutral during the Second World War. The military alliance between the USA and the Turkish Republic was only one of the reasons behind the emerging popularity of American culture among Turkish politicians and citizens. In addition to the spread of Hollywood culture through movies and television and the Marshall donation that was aimed at supporting contemporary life in Turkey, there were other factors that created Americanist winds both in the cultural and political life of the Turkish Republic in the 1950s and 1960s. The image of the ideal American family became a new model for Turkish domestic life. The marriage rate increased while the divorce rate decreased during this period. The ideal image of the American woman who gave birth four or five times and devoted the utmost attention to the perfection of her house and her own physical appearence started to appear in Turkish women's magazines. The government also encouraged women to be mothers and wives by glorifying the status of American families in the formal speeches. See Hürriyet Konyar (1993) Çok Partili Hayata Geçiş Sürecinde CHP’nin Yeni 'Çağdaş' Türk Kadını, Tarih ve Toplum, 120 , pp. 49-56.

[14] Serpil Çakır (1994) Beyaz Konferanslar, Tarih ve Toplum, 231, pp. 40-48; Serpil Çakır (1996) Osmanlı Kadın Hareketi (İstanbul: Metis Yayınları).

[15] The Academy of Fine Arts was renamed as Mimar Sinan University, which is one of the leading universities in contemporary Turkey, especially for arts and architecture, on 20 July 1982.

[16] Bac, Turkish Women's Predicament, p. 304.

[17] Ibid., p. 307. For further readings on women's social history in Turkey, see: Deniz Kandiyoti (1997) Gendering the Modern: on missing dimensions in the study of Turkish modernity, in Bozdoğan \& Kasaba (Eds), Rethinking Modernity and National Identity in Turkey, pp. 113-132; 
Şirin Tekeli (1998) Birinci ve İkinci Dalga Feminist Hareketlerin Karşılaştırmalı İncelemesi, in Mirzaoğlu (Ed.), 75 Yilda Kadınlar ve Erkekler, pp. 323-336.

[18] Zehra Arat (1998) Kemalizm Ve Türk Kadını, in Mirzaoğlu (Ed.), 75 Yılda Kadınlar ve Erkekler, pp. 51-69.

[19] Ibid., p. 64.

[20] Gürhan Tümer (1998) Cumhuriyet Döneminde Yabancı Mimarlar Sorunu (İzmir: Mimarlar Odası İzmir Şubesi Yayını).

[21] Yasemin Sayar (2000) Türkiye'de Modernleşme ve Milliyetçilik: Milli Kimlik sorunu ve Mimari İfadesi, Mimarlik, 291, p. 51.

[22] http://virtual.finland.fi/finfo/english/women/archi_women.html (accessed 20 February 2004).

[23] Jitka Maleçkova (1998) Kadın ve Bir Milletin Kaderi Milli Uyanışın İk dönemlerinde Kadınlara Biçilen Rol, in Tarih Eğitimi ve Tarihte 'Öteki' Sorunu, (İstanbul: Tarih Vakfı Yurt Yayinlar1), pp. 201-214.

[24] Yeşim Arat (1997) The Project of Modernity and Women in Turkey, in Bozdoğan \& Kasaba (Eds), Rethinking Modernity and National Identity in Turkey, pp. 95-112; Leyla Kırkpınar (1998) Türkiye’de Toplumsal Değişim Sürecinde Kadın, in Mirzaoğlu (Ed.), 75 Yılda Kadınlar ve Erkekler, pp. 13-28.

[25] Neslihan Dostoğlu (2005) Dünyada ve Türkiye'de Değişim, Kadın ve Mimarlık, in Neslihan Dostoğlu (Ed.) Cumhuriyet döneminde Kadın ve Mimarlık (Ankara: TMMOB Mimarlar Odasi), p. 39.

[26] Gwendolyn Wright (1986) On the Fringe of the Profession:women in American architecture, in Spiro Kostof (Ed.) The Architect (New York Oxford University Press), pp. 280-309.

[27] Yekta Özgüven (2002) Türkiye'de Kadın Mimarlar (1934-1960), in ÇağdaşMimarlık Sorunları Mimarlık ve Kadın Kimliği (Istanbul: Boyut Yayın Grubu), pp. 79-100.

[28] Güzel Sanatlar Akademisinin Otuzuncu Senesi Münasebetiyle, Arkitekt, 1(1932), pp. 54-58.

[29] Gerede Halkevi, Arkitekt, 3 (1934), pp. 110-111.

[30] Harika Söylemezoğlu, unpublished roundtable speech, Türkiye'nin Kadın Mimarları organized by Yapı Endüstri Merkezi, 13 September 2005, İstanbul, Taşkışla.

[31] Karamürsel Halk Evi, Arkitekt, 5-6 (1936), pp. 142-144.

[32] The People's Houses were the propaganda organs of the single-party regime that aimed to mobilize the most prominent intellectuals loyal to the regime. This propaganda also drew on peasant ideology that included anti-urbanism, anti-industrialism, and the glorification of villages and village people. M. Asım Karaömerlioğlu (2001) The People's Houses and Populism during the Single-Party Era in Turkey, Toplum ve Bilim, 88, pp. 163-187.

[33] Zeynep Kezer (1998) Contesting Urban Space in Early Republican Ankara, Journal of Architectural Education, 52(1-4), pp. 11-19; Gülsüm Baydar Nalbantoğlu (1997) Silent Interruptions: urban encounters with rural Turkey, in Bozdoğan \& Kasaba (Eds), Rethinking Modernity and National Identity in Turkey, pp. 192-210.

[34] Kayseri Halk Evi, Arkitekt, 4 (1937), pp. 107-109.

[35] Ankara Etlik'teTek Ev, Arkitekt, 4 (1937), pp. 110-111.

[36] Şehremini Halk Evi Proje Müsabakas1, Arkitekt 9 (1938), pp. 253-256.

[37] Kadıköy Halk Evi Proje Müsabakas1, Arkitekt, 2 (1938), p. 48.

[38] Mardin İmar Planı, Arkitekt, 3-4 (1949), pp. 66-70.

[39] Çanakkale Meçhul Asker Abide Müsabakası, Arkitekt, 3-4 (1944), pp. 52-56.

[40] Istanbul Broadcasting Studios Competition, Arkitekt, 14 (1945), pp. 143-148.

[41] Ankara Sinema Otel Kompleksi, Arkitekt, 11-12 (1946), p. 257.

[42] Şişli Maliye Binası, Arkitekt, 9-10 (1946), pp. 206-207.

[43] Bursa Halk Evi Proje Müsabakas1, Arkitekt, 1 (1938), pp. 16-20.

[44] İzmir Fuarında Çocuk Esirgeme Kurumu Pavyonu, Arkitekt, 13 (1944), pp. 198-199.

[45] Adana'da Memur Teknisyen ve İşçi Konutları, Arkitekt, 16 (1947), pp. 201-204.

[46] Bac, 'Turkish Women's Predicatement', p. 315. 
[47] Şirin Tekeli (1995 reprint edition), 1980’ler Türkiye'sinde Kadınlar', in Şirin Tekeli (Ed.) 1980'ler Türkiyesi'nde Kadın Bakış Açısından Kadınlar (İstanbul İletişim Yayınları; first published in 1990), p. 31.

[48] Yekta Özgüven (2005) 1934-1960 Yılları Arasında Türkiye'deki Mimarlık Okullarından mezun Olan Kadın Mimarlar Üzerine Bir Değerlendirme, in Neslihan Dostoğlu (Ed.), Cumhuriyet Dönemi Mimarlğ̆ ve Şehirciliği Cumhuriyet Döneminde Kadın ve Mimarlık, pp. 54-55. Equal earnings for men and women were legally guaranteed in Turkey. However, legal regulations about equal earnings do not cover promotion opportunities, which have never been the same for men and women either in the state or private sector in Turkey.

[49] Özlem Erdoğdu Erkarslan (2005) Türkiye'de Kadın Mimarlar ve Cinsiyet Ayrımcı Çevre Sorunu, in Dostoğlu (Ed.), Cumhuriyet Dönemi Mimarly̆̆ ve Şehirciliği Cumhuriyet Döneminde Kadın ve Mimarlik, pp. 69-80. 